\title{
Legal dynamics in a border area:
}

\section{Between customary law and state law}

\section{NEBI BARDHOSHI}

This article considers factors that have effected and influenced the continuity of the customary law named the Kanun of Lek Dukagjini in some areas of Albanian and Kosovo. It draws on ethnographic data on the border area villages between Albania and Kosovo to discuss the dynamics and tensions that are created between state and non-state law vis-à-vis justice in highly complex and problematic social, economic, and political contexts. Customary law and state law seem to be two conflicting legal ideologies. However, the article considers everyday settings where people make use of both legal systems in order to regulate matters especially related to property issues. The new legal realities create around property ownership imply new type of relations vis-à-vis family and kinship structures which oscillate between the two systems.

* Key concepts: legal plurality, legal dynamics, equality, inheritance, land distribution.

\section{Contextualizing Legal Dynamics}

Whilst the states, Albania and Kosovo, on both sides of the borders, do not recognise Kanun ${ }^{1}$ (customary or traditional law) as a normative and legal entity, this law is exercised in the border areas between Albania and Kosovo. 
This is namely in the highland villages of northeast Albania and Dukagjini plains in Kosovo. The article considers ethnographic data on these villages to examine border interactions in relation to Kanun: these accounts include property disputes.

Border interactions provide duplicitous and dynamic settings: two distinct political and social areas bring out the interplay between legal systems and contribute to so-called pluralist and centralist perspectives which have been much debated in legal anthropology scholarship (cf. Griffiths 1986; Benda-Beckman 2002, 2006, Tamanaha 1993). The question of moral legitimacy of the law bears on anthropological conversations of legal pluralism versus legal centralism, (see Pardo, 2000a, 2000b, 2004, Pardo \& Prato, 2010, Bardhoshi, 2010).

The so-called Kanun of Lekë Dukagjini is an un-codified set of laws that were firstly codified by a Franciscan priest named father Shjefen Gjeçovi at the beginning of XX century (Gjeçovi 1972 [1933]). ${ }^{2}$ Often, researchers during communist period employed quite a metaphorical language such as crumbs, clots, rudiments, remnants, in order to describe and address the practice of Kanun (cf. Zojzi 1976). Recently, some researchers discuss transitions to argue against originality in the present practice of Kanun (cf. Tirta 2006: 371396). The misinterpretations on Kanun today draw on an essentialist perspective where Kanun is considered more as 'essence' rather than process (see Bardhoshi 2013).

On both sides of border, Kanun operates in context of modern state. Moving beyond so-called post-socialist anthropology I suggest that rather than 'unipost perspective' Kanun has to be analysed in 'multiple post context (e.g. in post-socialist, in post-war, post-dictatorial, post colonial etc.), In Kosovo, the role of the international community after 1999 contextualizes the multitudes of 'posts' by giving an end to the war and also assisting the new state of Kosovo to have its law enforced and jurisdiction maintained under the so-called capacity state building policy. However, the post-war situation and the creation of the new state in Kosovo are redefining the roles of Kanun in praxis. The case of Albania could also be analysed as multitudes of posts, if we analyses the phenomenon in longue durée terms. Overall, the existence of Kanun could not be analysed without considering the history of state in this region. Thus, term 'post-socialism', is analytically inadequate as long as it creates the false image as though people life was exclusively forged by socialism.

Nevertheless, presently, both states have 'imported' the neo-liberal ideology and are committed to fulfilling the so-called International Standards for a functional market-base type of democracy. In either case it is possible to discuss a neo-liberalization of the state base rights. The practice of importing the law is closely related to the origin of modern state and modernity in this area. The imported law is seen at the same time as mechanism of modernization and also as the source of legitimacy of its own and political 
reforms. The logic of moral legitimacy of the law imported is based on idea that laws are borrowed by the most civilized countries and it is envisaged that those laws will make possible social evolution of the people who will be subjects of this laws (cf. Benda. Beckman, von 2006, Bardhoshi 2013). The state law, in this case, is not called to represent any kind of morality of the majority, but to effect change, 'to progress' the society. Although Kosovo is facing problems in being recognized as a state, it is undertaking substantive economic and legal reforms. Reforms in both countries are imposed by the international community in general and European Union, in particular. This State law becomes an imported phenomenon. As such it is faced with what Giordano and Kostova (2002:76), in their work on the social production of mistrust, term a 'persistence of a century-old divide between state legality and the legitimacy of norms, institutions, and social norms' (Giordano \& Kostova 2002: 76, see also Prato, 2010).

In both Kosovo and Albania a clash is evident with an imported state law; in both cases locals long familiar with customary law have yet to internalize state law. Thus, in Pospisl's terms, dialectical relation occurs between an 'authoritarian' law versus a traditional grounded in 'traditional' legitimacy; further, both local communities are socialized into believing Kanun or customary law is just (Pospisl: 1978: 193-232). Finally, both areas are marked by internal and external migrations, where migrants maintained economic and familiar relations with the areas. The allowance of dual citizenship makes it easier for conditions of legal plurality even at this social and political level (See Law No. 03/L-034).

Giving due consideration to classical debate in legal anthropology about the transplanted laws and cultural context, the relations between authoritative laws and customary laws, and the question of moral legitimacy of law, the article will attend to various issues related to property rights on land, in context of duality between customary law and state law. I turn first to an overview of historical perspective on state law legitimacy of Albania and Kosovo before considering ethnographic cases on the border areas. I consider data on principal of equality on land distribution of family land property, bringing out gendered issues in relation to inheritance rights. My data further consider issues of common property and sacred land privatization in village settings in condition of neoliberal ideology. The foci will illustrate the contradiction between state law and local practices.

\section{Modern State, Kanun and Moral legitimacy of Law}

The communist state in Albania was faced with a haemorrhagic legitimacy lost, among other things, due to the radical reforms it had on land property in the notorious process known as collectivization. This process led to mistrust of and moral challenges to authority of the government by the populace. It also 
produced a collective glorification of the traditional system prior to the installation of the communist regime. In order to re-instate the lost legitimacy, at the start of the 1990's, the communist government in Albanian decollectivised (privatized) the agricultural land of the socialist collective farms by following the principle of distribution rather that of restitution (De Waal 2005, Bardhoshi 2011). The law on land distribution explicitly denied the right of inheritance to all those individuals whose land had been taken priory by the communist government. The same law also did not recognize any prior form of inheritance right and/or property borders in the process of decollectivisation of agricultural land. A newly democratic government promoted the neo-liberal principles and in 1993, a new law was issued where all existing un-decollectivised land had to be distributed following the principle of restitution which meant that former owners via inheritance or acquisition had the right to claim the land that the communist state had taken from them and collectivized afterwards. This law which entitled former owners to their former land property came after a few areas in Albania had already implemented the decollectivisation of land following the distribution principle. Further, in some others especially in the areas of northeast of Albania, the people had already written their own history because instead of distributing the land according to state law they had observed the rules of Kanun in dividing the agricultural land of state or cooperatives farms.

Regarding history of state legislation on land, in Kosovo, the situation is rather different due to the moderate nature of Tito's socialism: either the process of collectivization was very much small in scale or it was carried out only for a short period of time in the areas due to the hilly or mountain type of the terrain. However, Kosovo faced another problem related to land property during Yugoslavia which was coming from the colonial type of policies implemented with different intensity by the state ${ }^{3}$. After the 1990 's, colonial type of policies was intensified vis-à-vis the state and law in this region. (Obradoviq 2005). In 1991 Kosovo elites wrote down a constitution demanding independence for Kosovo and the creation of the state of Kosovo; this step gave rise to Kosovo state structure parallel to that of Belgrade one and initiated Kosovo's peaceful resistance. This constitution was eventually rejected by the Yugoslavian authorities. However, it was embedded in the modernist spirit and foresaw the construction of modern Kosovo state within the boundaries of Yugoslavia (see Vickers 1998). Moreover, it acknowledged the state law as the sole source of justice in the territory that the state administered.

The turbulent political situation between Kosovo and the Yugoslav authorities created a fertile social environment for the flourishing of legal plurality because it enabled Kanun to continue. The Albania's in Kosovo found themselves between and betwixt three paralleling and often conflicting legal systems: the parallel and conflicting legal systems of Kosovo and Serbian governments, and Kanun that paralleled and conflicted with both legal 
systems. In the post-war period (1999-2010), the state law in Kosovo did change again in order to fulfil the international criteria. The changes were several but, aimed, among other things to create a new type of citizenship, and to frame and regulate legally all kinds of property, including here all transactions related to land property

Yet, an overall observation of both Kosovo and Albania state law bring out many contradictions which make it possible also to speak of an internal plurality within the state legal system. In both states, the formal legal system is represented by the 'unclearness of concept' definitions, a superposition of laws, and an inflation or hyper-legislation in the name of modernization; all these factors have strongly impacted people's perception on law by challenging state legislation legitimacy and justice administration. The uncertainties that the formal legal systems portray for everyday people, in both societies, have made them rely more and more on the rules of Kanun as a mechanism for justice administration. Lastly, there are minimum discussions and debates within academic circles in both Kosovo and Albania over the impact that Kanun has especially in regulating matters related to land property. Often these debates neglected Kanun's role at micro-levels in administering land distribution and all other matters related to land transaction.

\section{Gender equality between Kanun and State law: Property Issue}

Kanun is regarded as a pre-state law or non-state law (cf. Yammamoto 2008) a production of both patriarchal lineage and kinship ideology that it was influenced superficially by Roman, Byzantine, and Turkish laws (cf. Elezi 1969). The founding principle upon which the very structure of Kanun rests is the principle of equality between men, a principle that takes different shapes and applications in different times and locality. Such principle is legitimized by the belief that people have a shared and common origin from a male ancestor. According to such ideology the symbol of equality and solidarity in a group was embedded in the concept of 'brother'. Thus, Kanun is shaped and it has shaped an egalitarian- patriarchal type of society. My long-term fieldwork especially on land property issues, in Albania and Kosovo has shown that Kanun, today, continues to operate in and regulates family relations especially matters related to property as it did during the communist period (Bardhoshi 2013: 63). The continuity of Kanun, parallel with the state law, is seen to have enabled the administration of justice and overcoming of conflict related to land property especially during the period of de-collectivization (Bardhoshi 2010).

The neo-liberalized state law, although recognizing the family unit as subject to property relation, claims and underlines the principle of equality of 
people regardless of their gender: this means that they can claim and attain a share in family property (Bardhoshi 2010). The Family codices on this matter, after World War two (WWII), have had different perspectives on the practical applications of this recognition: nevertheless these always observed and underlined the principle that family member regardless of their gender do have a claim and share in their family property (Law Nr.2004/32, in Kosovo, Family Code in Albania, 2007, see also Kaser 2008) Albania signed and ratified the international covenant against any types of discriminations against women (CEDAW-1993), as well as all other covenants and respective charters concerning human rights and discrimination. But, on the other hand according to Kanun in principle and praxis, only paternal male brothers have the right and are entitled to have an equal share of family property, while daughters and sisters have no right to claim any immobile property, and are only entitled to a very limited right to claim some moveable property (Bardhoshi 2011). This system of property distribution within the family unit continues even today in every village of the district of Dukagjini in Kosovo and in the villages of northeast Albania.

A clear example of how Kanun law still prevails is the fact that even in the present, the villages continue to retain their patrilocal or virilocal and exogamic nature. The sole heirs of a land property continue to be the male offspring of a family. Bothers build their houses in the property they inherit, near to each other and near to their paternal house. Their sisters are married outside the village and they are excluded from a share in the family immobile property. While I was writing this article I was informed that in a village where I had carried out fieldwork a year ago a young man and woman had fallen in love with each other and against the will of their parents and against the exogamic rules within the village they decided to marry.

The village, 'Kala' (a pseudonym) used to be exogamic and females were married outside the village because people believe they originated from the same male ancestor. I was put in a very difficult situation when I was asked by a member of this community to given an opinion on this matter. I was interrupted in reply: I began by saying that according to the family codex in Albania such a marriage was allowed. However, the wife of the person that asked me for an opinion intervened by saying 'Come on, please, Nebi, leave the Codex alone, only the pullet (police) can solve this matter.' Later I came to know that the state police had intervened to solve the matter by asking the two families to sign a declaration of non-sanction against their children who had decided to marry without their permission and who had broken the exogamic rule. Though both parties were 'forced' to sign this declaration, discussions that people were having on this issue held forth that the young male had lost his right to return to his father village. According to the interpretation of an old man, he had also lost his right to inherit land from his father. Yet, the latter interpretation was challenged by others because according to them the loss of inheritance was not just even in extreme cases as 
this one because there is "no man without the right to a share in his father property'.

Moreover, in cases of divorce, female members of a family unit would be hosted and taken care by their brothers after parent's death. Currently, as official statistics and fieldwork data show, divorce rates are increasing in both Albania and Kosovo. More and more female members of a family are returning to their villages of origin to live in either their paternal or brother's house. The return of a divorcee sister in the paternal or brother's house may be subject of tensions and discussion especially if she is mother to a male child. The civil courts often give the right, in case of divorce, to the mothers to take care and raise the young children. In one of my case studies, the female divorcee was obliged to leave her parental house and native village in order to avoid the conflict between she and her brothers because she was mother of a young male child. The matter in conflict was that the young boy whom, though related to his mother's brothers as nip (nephew), was unacknowledged by his dajat (maternal uncles) as a member of the family. The conflict between sister and brothers intensified as the child was growing. To avoid further deterioration of the situation, she left her paternal house and natal village. However, the case became a matter of discussion in the village. Some inhabitants held the view that the biological son of a female member of the family was entitled to the same property rights as the biological son of a male member, while others held the view that only the sons and their male offspring are entitled to inherit immobile property in the village.

Nevertheless these arguments relate to why females do not have access to family immoveable property vary. In areas of Dukagjin plain of Kosovo, the female is believed to have the right to claim her father's land property; however, it is not really acceptable for her to raise such claim, because such act would bring shame on her brothers. The right of the female to claim and inherit a share from her family immobile property is called miraz. The term seems to derive from the ottoman work, mirass, which mean inheritance without restriction to mobile of immobile property. The inhabitants of these areas whom I researched do not recall any specific case where sisters have claimed their right to a share in their father's immobile property when they had one or more brothers. However, I found across three cases in Rogova district and Dej village in Dukagjini's plain, where the daughters, in the absence of males, had claimed the right to their father's property against their first patrilineal cousins. In 2010, while I was doing fieldwork in Rogova village I was told of two related cases; however, my interlocutors hurried up to close the discussion on the matter arguing that this is a very delicate issue and it needs to be solved within the village. In the specific cases the right to property were raised by the sons of the daughters in two separate families where their grandfathers had no male inheritors. Although they had attained the right to use the given land property, they had, no right to sell it. 
The dervish ${ }^{4}$ of Dej village told me about two analogous cases he had come across while serving in this area. I should point out that the dervish was feeling uncomfortable through out the whole interview on this issue. The first case had happen around 30 years ago while second around five years ago. The dervish through out the interview was pointing and underlining the fact that the word, miraz, means bad omen. According to him experience has shown that when a property was taken following the miraz rule bad things had really happened. Such properties, according to him, often were not very much fertile or not fertile at all as they used to be before. The female's heirs not only gained an unproductive land, but also they lost their ties with their paternal kin. The belief that miraz land is unproductive land is very much widespread in the areas of Dukagjini's Plain where the Dej village is located.

Nevertheless, a member of the family that had gained a land property following the miraz rule said to me that he was very happy to have inherited something from his maternal grandfather and he did not repent at all to have done so. He explained to me that this land was not really productive due to his lack of work on it for production reasons. The young man explained that he had ploughed the land the previous year not to be productive but to publicly tell his maternal kin and village that he was the new owner.

In the areas under study there is another argument that entitles female heirs to a share on their fathers' immobile property. According to this argument sisters are entitled to claim half of their brothers claimed share because according to Kanun, a female is worth half of a male. Nevertheless, such norms are part of people's social memory and examples or cases when females have inherited immobile property following such a rule are very rare. In the city of Prizren, Kosovo, it is said that the female has the right to claim immobile property from her brothers but not on the house where the brother or brothers live. Her request to property should be accompanied by a very valid argument, such as in the case of poverty or in case of sisters' dissatisfaction with her treatment when she came for t'pame (regular visit to parental house). An interlocutor from this area said that if his sister did not have enough income to live then as her brother he was obliged to financially assist her. This principle is well accepted and presented everywhere in this region and it implies that in one hand females do not have the right to immobile property but one the other brothers are obliged to help their sisters out in cases of poverty.

In practices, even in cases when the female attains a part of her family immobile property as miraz she is obliged to sell it to her brothers because she is not allowed to build on it. The right to build on father's land property is granted only to the brothers. In earlier times (four to five generation ago) cases arose of nephews building houses on grandfathers' land inherited by their mothers. For example, the brotherhood of Sefollit in Vranisht village is said in part to have originated from a nephew who was allowed by his maternal uncle to build a house on his maternal grandfather land. However, 
even in such cases the nephew gained such a right because they were transformed into 'soul son' to their uncles. This was a form of rite of passage that transforms socially a son of a sister into a son of sister's brother. It enables the individual male to have equal rights and claims on his maternal grandfather property. Presently, such cases are not to be found. However, that these occurrences in the past serve to strengthen the patriarchal and patrilinear kinship ideology. Thus, as the discussion brings out, while the state law fosters equality between gender within the family unit and entitles both male and female to an equal share in family's property, Kanun principles are still being applied in everyday life; these are principles that foster equality between men and disparity between men and women.

\section{Land, Market Principles and Kanun}

At a micro level, the land market acquires a specific relevance in understanding the clash between neo-liberal principles of freedom to property, and the 'local realities' that structure such a right following specific cultural traditions. My data shows that the real estate market on land, in both sides of the border is generally organized along Kanun principles rather than neo-liberal one. In the villages of Northern Albania, the owner of the house has the right to sell his property by firstly offering it to his brother or brothers, whom in most of the cases are also his neighbours. Brothers are considered to be equal to this right, even in cases where they have different mothers but the same father. Neither age nor a different religious belief in cases when one or more brothers have changed their religion plays any role when it comes to the offer/right to buy the share of father's land from a brother, because as the locals express it ' a brother remains and is still a brother'. However, as noted earlier, in the case of inheritance, female members are excluded from the right to an offer from their brothers either to buy their fatherland or to sell it. Thus, only male enjoy the right to buy, sell or donate land property.

I now turn to consider how the sisters/ daughters refrain from using their entitlements under state law to property from their native family. Often, brothers following Kanun demand their sisters make official written declarations renouncing their part of the share so that the given property can be registered under the brothers' name. When asked why such practice is followed, the most frequent answer that female interlocutors gave me is that they regarded it a shameful act to take a property that according to them belonged rightfully to their brothers. Along this line, female research participants would often say tell me that they were afraid of the inherent risks of interrupting both economic and social relations with their patrilineal family should they take the properties as they were entitled to under state law; this was a risk that no one is willing to take. I repeatedly addressed the very same question throughout my fieldwork in these areas and the answers were often 
quite the same. In 2008, in Golaj village, one of my research participants, declaring that she would not even dare to think of demanding a share from her fathers' property, said:

I would never bring shame on my brothers as well as my father. I am married and I want to have the door open at my brothers. When a female is born, she is considered a foreigner, dere e huaj. I am raised like that and I think like that.

Another woman in this village similarly noted to me: to be honest I don't think that it is just that woman does not have the right to claim from her fathers' property. To me both son and daughter are equal.' I asked her what would happen with her daughter. She replied that 'I don't know, I wouldn't like my daughters to be left with nothing, but at the end, it is their father who decides'. Two years later, in another village, I was obtaining similar data. In Rogove, in Kosovo, a woman who owned a hairdressing shop that she opened with the help of her brothers who are considered to be rich in this area was adamant about Kanun law in this regard. When I asked whether she would claim a share from her father's property, she sharply answered: 'I don't even dare thinking about it because I don't want to break the relations with my brothers!'

Probably, the most striking differences between North Albania villages and Kosovo is the implementation of Kanun legal principles: these are related to the father's moral and juridical authority. In Kosovo, especially, in Dukagjini Plain, the father still preserves some elements of his ownership rights even in cases when his family has been spilt and the land shared between his sons. This means that if one of the sons is willing to sell his inherited land firstly he must ask for his father's permission to do so. Without such permission, the son cannot sell the inherited land. One of my participants, Rrustemi, 72 years at the time of my fieldwork, lives with one his sons in one of the villages of Dukagjini Plain. He took up residence with this son after splitting the family at which time he also divided his property in equal shares between his sons. After the separation, each of his sons built a house in their paternal plot where they now live with their respective families. At one stage, I asked him while we were having some coffee in the village's coffee house his views on any sons wishing to sell the inherited property. I was aware that one of Rrustem's sons had actually wished to sell some of his land and had been forbidden to do so by so Rrustem even though they had been divided from 'joint family' into the new families for quite sometimes.

Immediately this question sparked a debate which included all the present in the coffeehouse. I suggested to Rrustem that as his son is now the man of the house, he was entitled to do whatever he wants in his house and with his property. I illustrated by giving examples from areas in Albania where this entitlement was given. However, Rrustem explained that in his 
area as elsewhere in Kosovo, as long as the father is alive, he continues to be considered the owner of the land, while his sons are only users of it. He noted that sons would only gain the full right to land ownership after the father's death. He also added, laughing, that 'at the end of the day I still have the papers of the land under my name and until my death for the state I am the owner'. So that was the case when the father was using both legal systems, that power given by Kanun could in turn be reinforced by state law which supported him as the original owner.

As my data indicate in Kosovo, unlike that of Albania, the father's figure remains strong. Some of the reasons for this persistence of the father's role and rights might be related to the weaker impact in Kosovo, comparatively, of the emancipatory war oriented by the state against patriarchy in both Kosovo and Albania. Secondly, until recently, the Kosovo family was an extended one meaning that father-mother and their unmarried and/or married offspring with their wives and kids all lived under one roof. In one case study, the family lived in the village of Rogova. This family until recently comprised 18 members: father-mother, 3 married sons, their wives and respective offspring. Three generations were living under the same roof. The brothers had built two houses of similar sizes near their father's house. These houses shared a common yard and one entrance. The surrounding wall of the yard was built in such way as to enable the brothers in the future, after their father's death when they would split, to build and have individual yards and entrances. Moreover, it can be said that in Kosovo the heads of the family play an active role in separating their joint families and also structuring how the family estate is going to be shared.

Finally, another factor that might have played a role in this can be attributed to migration. Most families in Kosovo were to a certain extent also transnational, especially in the pre-war period and due to the high level of emigration of people outside the country. The transnationality of Kosovo family has been amplified also by the breaking down of Yugoslavia, because in many cases family members would acquire a new nationality in the countries where they resided and carried out their economic activity as it is the case of people from Has region; the members of this area had the monopoly of bread-making and pastry making, and migrated all over former Yugoslavia. The migrants usually were adult married male members who emigrated for work either in other countries of Yugoslavia or in other European ones. They would leave their wife and children behind. Migrants fathers' original family would provide support for their sons' family. Under such circumstances the father's family became the epicentre of a joint economic activity for its members, as far as migrants would send their revenue to their fathers who in turn took care for sons' family left behind. Thus, father's role became even more important in keeping the family together through his control on family and offspring's economies. In cases where the 
family had split due to emigration reasons, usually, it was considered as an unlucky and ill-fated one in economic activity 5 .

In north Albania, fathers' authority is no any longer as strong on sons' land property after they have separated from him as it is presented in Kosovo. Various interlocutors told me that the householder's institution of a strong authoritative father was also present in north Albania but has been eroded with time. In either cases, the creation and/or continuity of a strong institution as that of the patriarchal household on issues related to land property relations, has helped to invigorate social relations and social structures related to land property: any transaction on land impacts directly or indirectly on the continuity of the given social structure and relation (Bardhoshi 2011).

\section{Trajectories of Village's Common Property in Neoliberal Times}

I now turn to examine the ways in which Kanun relates to matters of villages' common property. Each and every village had a common land property that was used for pasturing and woods. Common village property was created at the founding of the village or by family donation or by both. Family donation was a custom called toke e dhuruar per shpirt (land donated for soul). Another term that it is used to identify this donated land is hajrat..$^{5}$ The villages of highlands in northeast and Dukagjini Plains in both Kosovo and Albania are composed, as indicated here, of family unit groups that are related to each other via 'real' or 'fictive' paternal lineages. Village configuration has also affected the way land property is structured. There are villages like Zymi, Romaja, Dede, structured along family units which belong to different religions -Muslims-Sunnite, Muslim-Bektashi and Catholics. In most villages of Albania and mountainous Kosovo, the memory of a common Christian origin is very much vivid for the Muslim population. Nevertheless, regardless of the religious background, the families of these areas continue to use the same system to divide land property which is organized along paternal male lineage.

Differentiating significantly from what happened with private land property, the destiny of common village property varied throughout the Balkan since the creation of nation-state. With the creation of nation-state and especially when Balkan states adopted the communist ideology village's common property became state property (Giovarelli and Bledsoe 2001). The state law as noted in the beginning neither recognizes Kanun as a source of law or the structures created by it. Thus. although the whole village as community in Kanun is regarded as legal personae subject to 'economic relation' and legal personae subject to a communal property, according to state law it is not known as such. Following this logic, villages' common property was often nationalized and transformed into a state property. It was 
in state sole power to decide what to be done with it. Even though the common village property was often nationalized by the state, in most cases, people continued freely to make use of such property on a daily basis ${ }^{6}$.

Village members on Albanian side for instance in Has and Bytyçi region have used Kanun in regulating relations on common village property. In some areas the land is privatized or given to usage by the state to private local, regional or national firms. However, in the first instance, this land has been occupied and virtually privatized by the members of the village who, in some case justified this act by referring to norms deriving from the tradition of Kanun that allows village members in case of necessity to seize it, or, in some others, they simply used the principle of the stronger. For example, in Golaj village to be located in Has region of Albania that used to have in four different areas common village property that locally was known under the name mera, a group of families without any justification or reference to Kanun norms, seized what was considered as the fertile part of the common property know as Hamalla. In some other areas, as in the case of Vranisht village, Has region of Albania, a good part of common village property was seized by force from individual members of the village. In seizing the land, an 'interested party' would initially plough the land symbolically or simply fence it. In instances where village members reacted, the parties wanting to seize the land would fiercely respond by saying that know this land was theirs and that nobody should dare to touch it. ${ }^{8}$

Presently, market-oriented governmental policies subjected the land to state privatization; land was either sold to private companies or to individuals. According to state law in most cases village members did not have the right of the first refusal for property. Village members say that it was much better when the state owned the land given the significant problems which has resulted from changes in ownership. Even though the state had its ownership of this property yet this land was considered to be a common village property and village members could easily access it. With privatization this situation has changed. The village cannot make use of it. In this case the state is privatizing decisively what were public resources of the village.

Further, resources related to use of the land extraction are at issue. For instance, the right to extract chrome minerals from the village property was seen to belong to those families which first discovered it in villages' common property. In Kosovo, chrome extraction is a right reserved only to village members. Now, the state is giving licenses for chrome excavation and construction of agricultural farms to private companies in these areas on both sides of the border. The process of privatization of village common property is layered and it includes an interaction between local, national and sometimes even transnational actors. 


\section{Different trajectory in Kosovo}

In Kosovo the history of common property follow different trajectory. Here I will give short accounts from my fieldwork. I start with an example of common property issue in village, Rogovo. Most part of the common village property was located in the centre of the village and around it. When Kosovo was part of Yugoslavia, a part of this land was given, by the state, to Serbian migrants to the area, a part was used to create a Roma neighbourhood, and the rest was considered until 1999 state property. With the end of 1999 war in Kosovo, a part of the common village property which was once state property was seized by individual members of the village whose private property was bordering with this property by using the pretext of vicinity, meaning that it was their right to do so because their property was at the border with it. Other members of the village seized it by using the pretext of economic necessity and they simply did not care about village's decision about this property.

As noted, one form of village common property creation was by donation from individual village members in the form of Hajrat (donated land for grace). There are at least two strong reasons why the memory of Hajrat land is more present in Kosovo than in Albania. This may be considered in terms of the soft nature of socialism in Yugoslavia that enabled to a certain extent the continuity of private property in Kosovo together with the practice of religion as a public activity. Nevertheless, the donated land in Hajrat form seems to have had several social functions that were not recognized by the state legislation. One of the contradictions that emerges between the two is related to the fact the state law does not recognized the category of 'sacred land'; thus, for the state law this land is equally subject to privatization. While during communism, the atheist law did not recognize this land, in turn, it consecrated the category of common property, enabling the continuity of both memory on land created by Hajrat and also its usage for common purposes. Meanwhile, the neo-liberalised legislation in contemporary Kosovo and Albania does not acknowledge the donor of this land as the rightful owner of it and, thus, allows its privatization to the higher offer. This process has fostered intense discussion at community level on whether Hajrat land should be privatized. When I asked one of the heirs of a person that had donated a land in the village of Rugove, Kosovo, why he does not privatize this land, he explained that even if he did so still in the memory of and for the soul the grandfather the land had to remain a public good. Yet, my interlocutor also explained to me that his family is unable to claim their right on this land because they lack the necessary documentation to prove the prior ownership to it. Throughout my fieldwork, people were uncomfortable about the issue and unable to comprehend how land that it is donated and basically given away for free by a person as public good for the community can actually be sold by the government today. 


\section{Conclusion}

This article examined a complex process relating to Kanun based on my longterm fieldwork in the border areas between Kosovo and North Albania. The article has brought out two contradictory legal systems through people's behaviour on equity related to land property rights and the market of communal and sacred land. Thus, the everyday life of the people between modern and traditional law has enabled the latter to create and be part of semi-autonomous social fields in which different aspects of culture are being negotiated (Moore 1978). These social fields seem to work as a habitat that enables the transmission and moral legitimacy of the Kanun knowledge as used to maintain male control over property and to secure social cohesion of the community, while strongly questioning and resisting the dubious neoliberal and legal integrity state policies. In micro level, many contradictions have been raised related to moral state law legitimacy such in case of privatization of land donated for soul. Many participants questioned the morality of the state law where it sought to appropriate the land donated for soul in order to privatize or to make it marketable. This did not meet with their approval. According to this local perspective after land is donated for soul, this kind of land is transformed into an inalienable thing.

The article brought out how the kinship ideology and Kanun on which the latter is legitimized, and which are in many aspects based on different values compared to those founded and promoted in state law, continues to dominate the field of local legal culture on land. This was while the state law was only a kind of 'side dish' that articulated only the legality of the given praxis. As illustrated, the everyday social environment of both sides of the border encompasses a 'legal habitus' composed on one hand by a functional Kanun and on the other, a very questionable state law. The systematic erosion of state law's moral legitimacy becomes traceable not only in its imported and authoritative nature, but also in terms of how the state moral legitimacy is negotiated and constructed by the people in everyday life.

\section{Acknowledgements}

I would like to thanks my collegue Olsi Lelaj for his fruitful comments on the first draft of this work. I am very grateful to Gilles De Rapper and Pierre Sintes for inviting me to be part of the International Research Project called Balkans from Below : Loca Reconfigurations and Individual Pratices Since 1990 (Albania, Bulgaria, Greece) (2009-2011). This projected has allowed me to extend my (C) 2013 Aequitas Publishing 
ethnographic research. Also I would like to express my deepest gratitute to the editors for their very good comments which have been very decisive in buliding a stronger and more organised theoritical argument.

\section{Biographical Notes}

Nebi Bardhoshi (PhD), Associate Professor, is a chair at Department of Ethnology at Institute of Cultural Anthropology and Art Studies in Tirana. He is author of the book, Border's Stones: Customary Law, Property and Social Structuration. Nebi has authored and also co-authored several scientific publications in field of social and legal anthropology dealing mainly with themes related to legal plurality, legitimacy, collective identity, customary law, postsocialism. His fields of interest also include the theoretical analysis of Albanian ethnographic thought especially on legal anthropology and its relationship to modernity.

\section{Notes}

${ }^{1}$ Kanun was named after the medieval prince Lekë Dukagjini (Zojzi 1962; Krasniqi 1977)

${ }^{2}$ Albanian and foreign researchers (cf. Whitaker 1968) who have dealt with Kanun have often expressed their worries for its disappearance in the course of modernity which coincided with the creation of nation-state as a result of state law expansion, especially after the Albanian state adopted the communist ideology (see Bardhoshi 2013).

${ }^{3}$ I plan to conduct further research on this issue.

${ }^{4}$ Families with one adult members have much more difficulties in economic terms. Migration was more profitable as long those who had emigrated do it singly, leaving other members behind. The living cost in the homeland was cheaper. In cases where the family was split, the number of the people who would emigrated was lower; when only one adult man was in family he was forced to stay at home or to emigrate with his family.

${ }^{5}$ The term seems to derive from a Turkish word that mean for goodness, for grace. It is believed that the donation of land would enable its donor to be graced by God whom in turn would give him a better life in the after life. Also it is believed that even the next generations after donor's death would be graced with goodness and prosperity. The donated land from which the whole community benefited would increase donor's prestige as well as of his family. Cases of Hajrat land are much more presented and remembered in Kosovo

${ }^{6}$ During communism, when all property was nationalized, the members of the village continued to make use of what once was village common property for both 
pasturing or woods. But, problems related to the village common property would start after the fall of communism when the village common property was privatized by individual subjects

\section{References}

Bardhoshi, Nebi (2011) Gurtë e kufinit. Tiranë: UET Press.

Bardhoshi, Nebi (2010) Diktatura e kusherinjëve dhe ideologjia e tregut të lirë. Journal of Jus \& Justicia, 56-67

Bardhoshi, Nebi. 2011. The 'Citizen' and the 'Transformation' Period in Albania: The Case of Tirana's Periphery in Prato\&Pardo eds, Citizenship and the Legitimacy of Governance: Anthropology in the Mediterranean Region, pp. 115-132.Farham, Ashgate:

Bardhoshi, Nebi (2013) Albanian Communism and Legal Pluralism, Ethnologia Balkanica, 16 Lit Verlag: 62-74. .

Benda-Beckman, Franz von (2002) Who's afraid of legal pluralism? Journal of Legal Pluralism 47:37-82.

Benda-Beckman, Franz von (2006) The Dynamics of Change and Continuity in Plural Legal Orders, Journal of Legal Pluralism, 5354:1-44De Waal, Clarissa (2005) Albania Today: A Portrait of PostCommunist Turbulance. London : I.B TUARIS.

Elezi, Ismet (1969) Karakteri i së drejtës zakonore gjatë pushtimit turk. In Konferenca e dytë e studimeve albanologjike, vëll. II. Tiranë: Universiteti shtetëror i Tiranës.

Giordano, Christian \& Dobrinka Kostova (2002) "The Social Production of Mistrust in Chris Hann (ed.) Postsocialism: Ideals, Ideologies and Practices in Eurasia, pp.74-92. London: Routledge.

Giovarelli, Renee \& David Bledsoe (2001) Land Reform in Eastern Europe. Seattle, Washington: Rural Development Institute.

Gjeçovi, Shtjefën (1972) Kanuni i Lekë Dukagjinit. Prishtinë: Rilindja.

Griffiths, John (1986) What is legal pluralism. Journal of Legal Pluralism 24:1-54.

Kaser, Karl (2008) Patriarchy after Patriarchy. Gender Relations in Turkey and in the Balkans, 1500-2000. Münster: LIT Verlag.

Krasniqi, Mark (1977) Krahinat etnografe të Kosovës. In Konferenca Kombëtare e Studimeve Etnografike. Tiranë: Akademia e shkencave e RPSSH

Moore, Sally Falk (1978) Law as Process: An Anthropological Approach. London: Routledge \& Kegan Paul.

Pardo, Italo (ed.) (2000) Morals of Legitimacy. Between Agency and the System, Oxford: Berghahn.

Pardo, Italo (ed.) (2004) Between Morality and Law. Corruption, Anthropology and Comparative Society. Farnham, Ashagte.

Pardo, Italo and Giuliana Prato (eds) (2011) Citizenship and the Legitimacy of Governance: Anthropology in the Mediterranean Region. 
Farnham: Ashagte.

Prato, Giuliana (2011) The 'Cost' of European Citizenship: Governance and Trust in Albania in I. Pardo \&G. Prato (eds) Citizenship and Legitimacy of Governance: Anthropology in the Mediterranean Region, pp. 133-151.Farnham: Ashgate.

Obradoviq, Milovan (2005) Reforma agrare dhe kolonizmi në Kosovë (19181941). Prishtinë: Instituti i Historisë

Tamanaha, Z. Brian (1993) The Folly of the 'Social Scientific' Concept of Legal Pluralism, Journal of Law and Society, 20 (2) 192-217.

Tirta, Mark (2006) Etnologjia e shqiptarëve². Tiranë: Geer. Original edition, (2003)

Vickers, Miranda (1998) Between Serb and Albanian: A History of Kosovo, Columbia University Press.

Whitaker, Ian (1968) Tribal Structure and National Politics in Albania, 1910-1950 in I. M. Lewis (ed.) History and Social Anthropology, pp. 253293. London: Tavistock.

Yamamoto, Kazuhiko (2008) The Ethical Structure of The Albanian Customary Law. Tiranë: Almera.

Zojzi, Rrok (1962) Ndamja krahinore e popullit shqiptar. Etnografia shqiptare 1:16-64.

Zojzi, Rrok (1976) Mbeturina të rendit fisnor në disa mikrorajone të vendit tonë, Konferenca Kombëtare e Studimeve Etnografike. Tiranë: Akademia e Shkencave.

Nebi Bardhoshi

Institute of Cultural Anthropology and Art Studies

Rruga Kont Urani Nr. 3.

E-mail:nedeba@yahoo.com 